Borneo Journal of Social Science and Humanities

DOI: https://doi.org/10.35370/bjssh.2020.2.1-09

e-ISSN: 2682-8235

(C) 2018, UCTS Publisher.

Submitted: 06 June 2020

Accepted: 11 June 2020

Published: 30 June 2020

\title{
Determinations of Tourist Outbound Travel Intention in Sarawak: Does Gender Really Matter?
}

\author{
Winnie Wong Poh Ming*1, Everlyn Toh Ting Ling ${ }^{2}$ and Chiew Huang Ping ${ }^{3}$ \\ ${ }^{1}$ Department of Marketing, School of Business and Management \\ University College of Technology Sarawak \\ ${ }^{2}$ Department of Business Administration, School of Business and Management \\ University College of Technology Sarawak \\ ${ }^{3}$ School of Postgraduate Studies \\ University College of Technology Sarawak \\ *Corresponding author: winniewong@ucts.edu.my
}

\begin{abstract}
Travel decision making has been studied comprehensively. Many travelers have expanded their range of choices, which preferred to travel to abroad instead of local destination. The aim of the study is to discover the significant determinants that leading outbound travel intention. Besides, the study also investigate the moderating effect of gender on outbound travel intention in Sarawak context. The current study employed Theory of Planned Behavior (TPB) as a theoretical foundation to test the determinants of outbound travel intention. The primary data and hypotheses were examined using SmartPLS. The study proposes 10 hypotheses, of which the data support 4. A person-administered questionnaire consisting of multiple item scales was developed. A quantitative survey was conducted at four selected entry points, namely Miri Airport, Kuching Airport, Bintulu Airport, and Sibu Airport. Individual travelers have been the focus of the research study. Non-probability purposive and snowball sampling strategies were utilized. A total number of 358 respondents took part in this study. Results indicated that online marketing communication, personal involvement, and novelty and knowledge had a direct influence on outbound tourism intention. A significantly negative relation between life satisfaction and eWOM and outbound travel intention. These significant determinants were played important parts in shaping the outbound tourism flow from Sarawak. Surprisingly, the study found that gender is only moderate the relationship between eWOM and outbound travel intention. The paper extends the existing literature regarding new responses variables which are associated with outbound tourism intention. It also provide a better understanding of outbound tourism behavior among the Sarawakian. Additionally, it provides insightful implications especially for Ministry of Tourism in Sarawak, Sarawak Tourism Organization, and tourism operators. Some theoretical and practical implications, limitations of the study, and recommendations for future research are highlighted in this study.
\end{abstract}

Keywords: Motivation, Outbound tourism, Sarawak

\section{Introduction}

The Malaysian outbound tourism market had been renowned as an emerging consumer demand (Mohd Hafiz Mohd Hanafiah, Zulhan Othman, Muhammad Izzat Zulkifly, Hazmal Ismail, \& Mohd Raziff Jamaluddin, 2010). Evidently, outbound travel percentage is forecasted to increase 3.5 percent a year and reach approximately 14.2 million trips by 2021 (Choong \& 
Borneo Journal of Social Science and Humanities

DOI: https://doi.org/10.35370/bjssh.2020.2.1-09

e-ISSN: 2682-8235

(C) 2018, UCTS Publisher.

Submitted: 06 June 2020

Accepted: 11 June 2020

Published: 30 June 2020

Hedrick-Wong, 2017). According to the report of Tourism Satellite Account 2018, expenditure abroad among Malaysia travelers are increased from RM38.9 billion in 2017 to RM41.3 billion in 2018 (Department of Statistic Malaysia, 2019). Today's many Malaysians' have a strong desire for outbound travel. This is due the combination of holidays and multi interesting packages of abroad travelling offered by travel agents during Malaysian Association of Tour and Travel Agents fairs (MATTA). Besides, low-cost and premium carriers has become general travelling method of transportation to all of us. Consequently, to travellers, travelling is at its most accessible ever and more affordable then it was before.

Travel behavior is very unique. Although in Malaysia is full with tourism activities, but it is an interesting to study why Malaysian travelers are likely to have outbound travel instead of travel locally (Mohd Hafiz Mohd Hanafiah et al., 2010). There is little is known about the travelers' intentions to travel abroad. Aziz and Ariffin (2009) commented the important of exploring the study on how people make their travel decisions and what they enjoy during the travelling. Therefore, the current research study intent pursues the following objectives: (i) to identify the most significant determinant that influencing outbound travel intention among Sarawakian; (ii) to determine the positive relationship between life satisfactions, online marketing communication, eWOM, personal involvement, and novelty and knowledge and outbound travel Intention, and (iii) to investigate the moderating effect of gender between chosen variables on outbound travel intention among the local people.

\section{Literature Review}

\section{Travel Intention}

Travel intention is an opportunity of travelling to a destination (Ahn, Ekinci, \& Li, 2013), which is based on attitudes, choices (Kim \& Kwon, 2018; Chen, Shang, \& Li, 2014; King \& Grace, 2013), psychological and the changes between motivation and action (Bai, $\mathrm{Hu}, \& \mathrm{Wu}$, 2009). Travel intention is also acknowledged as the result of individual perceptions from previous experiences (cognitive and emotion). In the context of Taiwan culinary tourism, International tourists were preferred to go night market to taste the different flavor of foods and experience the local unique culture (Tsai, 2015). The study of Yiamjanya and Wongleedee (2014) found that the desired foods and attractive traditional market in Thailand were significantly drive a tourist to visit the Thailand. In the context of this study, outbound travel intention is referred to likelihood of an individual to travel to tourism destinations. The more powerful the determination of individuals to visit travel destination, the more probable they visit that location (Lu, Hung, Wang, Schuett, \& Hu, 2016). Subsequently, it is essential to investigate travel intention and comprehend its influence on the tourist behavior ( $\mathrm{Su} \&$ Huang, 2019).

\section{Life Satisfaction}

Life satisfaction is acknowledged as an individual who had a good feeling of well-being, meaning, and fulfilment (Chen, Lehto, \& Cai, 2013). It reflected the degree of an individual's needs, goals, and aspirations are fulfilled (Bai, Hung, \& Lai, 2017). In others words, it is comprehended as an individual's level of favorable evaluation of the overall quality of life (Veenhoven, 1996). As noted in the literature, a sense of happiness also can be understood as an individual's overall enjoyment of life (Tsaur, Yen, \& Hsiao, 2013). Travelling has been found as one of the leisure activities that increase happiness, reduces stress, and create healthier lifestyle (Dillette, Douglas, \& Martin, 2018). It contributed to psychological health as a part of 
Borneo Journal of Social Science and Humanities

DOI: https://doi.org/10.35370/bjssh.2020.2.1-09

e-ISSN: 2682-8235

(C) 2018, UCTS Publisher.

Submitted: 06 June 2020

Accepted: 11 June 2020

Published: 30 June 2020

life satisfaction by providing opportunities to pursue a social interest, rest, and prevent boredom and depression (Chen, Petrick, \& Shahvali, 2014). A previous study has confirmed between life-satisfaction and people intention to move aboard (Ivlevs, 2015). This implies how life satisfaction has influenced the intention to travel of tourist.

\section{Online Marketing Communication}

Marketing communication via online is growing rapidly. It is a process of message transmission associated with the promotion and defined as the fourth marketing mix component (Angelopulo, 1996). The instruments for marketing communication include advertising, sales promotion, personal selling, and public relations. All these communication instruments are used to reach the communication messages to the targeted audience in the specific market. As for tourism product, it is consisted of tangible and intangible products (Krippendorf, 1987), such as, travel, accommodation, and services provided. As such, marketing communication served as an important communication tool that entail the transmission of destination image, accommodation, and service provided by the service provider that led to travel intention. The use of celebrity endorsement as the advertisement were highly influenced destination choice especially Gen. Y (Chan, Lee, \& Wong, 2018). Good quality of travel agency results in the intention to revisit the destination (Soleimani \& Einolahzadeh, 2018). The communication message of public relations also had been found to influence travel destination intention (Jain, 2014).

\section{Electronic Word-of-Mouth (e-WOM)}

Word-of-mouth (WOM) is defined as a physical conversation with a non-commercial practice (Arndt, 1967). Conversely, the advent of the Internet has extended this principle to online context and known as electronic word-of-mouth (e-WOM). EWOM is easier to reach a wide targeted market (Abubakar \& Ilkan, 2013). The uses of social networking, namely, Facebook, Instagram, Twitter, and others had made extensive use of e-WOM in the tourism industry (Singh \& Srivastava, 2019). This, in turn may drive intense communication among the tourists, travel agencies, government, the hotels, and other service providers who involved in online networks (Amalia, et al., 2018). Moreover, visitors can definitely to update and upload their travel activities, write stories, share their travel photo and sharing their past experiences. All these shared information are important source of information to travels (Pan, MacLaurin, \& Crotts, 2007), reference for other tourist's future destination (Pabel \& Prideaux, 2016), and as estimation of the costs or benefits of travel destination (Chen, Shang, \& Li, 2014). Positive experienced visitors in services, products, and other sources are able to contribute revisit intention and spread positive e-WOM concerning destination amongst tourists (Amalia, et al., 2018). Evidently, the reviews message of Facebook friend had found to influence the hotel booking itself (Ladhari \& Michaud, 2015).

\section{Personal Involvement}

Personal involvement is described as an interest in a product caused by a specific situation with driving characteristics (Rothschild, 1984). It also describes an attitude that formed by individual differences and self-experience (Madrigal, Havitz, \& Howard, 1992). In tourism context, personal involvement is referred to a state of inspiration that caused by a connection between a positive attitude and self-concept (Johnson \& Eagly, 1989). For travel intention, it involves a high personal involvement as the individual who will invest more efforts and time to search and plan for the vacation. The principle of involvement changed from consumer 
Borneo Journal of Social Science and Humanities

DOI: https://doi.org/10.35370/bjssh.2020.2.1-09

e-ISSN: 2682-8235

(C) 2018, UCTS Publisher.

Submitted: 06 June 2020

Accepted: 11 June 2020

Published: 30 June 2020

behavior toward leisure behavior, which is related to long-term involvement (Hulusic \& Rizvic, 2013). This long-term involvement lead to individual's experience, image, and visit intention (Shih, 2009). Evidently, an individual tourist who has high personal involvement at the pretour research will certainly suggest greater destination verifications (Li, 2014). It is therefore to confirm that tourists who has extraordinary personal involvement will inspire individual intention to travel.

\section{Novelty and Knowledge}

Novelty is the sources of enjoyment, surprise, ease of dullness (Crompton, 1979), and experience, such as finding a nature-based attraction, events and activities, and attention from others (Park, Mahony, \& Kim, 2011). Seeking novelty is known as curiosity-driven, feeling seeking, and exploratory driving (Jang \& Feng, 2007). Novelty and knowledge is one of the components that influence the travel intention of tourists. It is an intrinsic impulse that influences the individual to observe, explore, control, and question (Lee \& Crompton, 1992). Tourists are preferred to go for familiar destination or s/he may choose to experience the unfamiliar destination. This implied that individual tourist has different preference to choose their destination (Elsrud, 2001). Consequently, novelty is important in tourism decisionmaking (Cohen, 1979) as novelty is natural by tourists, and the search for numerous types of the novelty will influence many leisure tourists to travel.

\section{Gender (as moderator)}

A review of literature illustrated that study of gender differences had been unnoticed in tourism behavior study (Carr, 1999). Thus, exploring the role of gender in outbound travel intention is therefore the focus of this study. Gender is not only biologically identified, but it is socially and culturally constructed (Okazaki \& Hirose, 2009). Gender played a moderating role in the relationship between overall satisfaction and individual's revisit intention (Han, Hsu, \& Lee, 2009). As noted, males and females are responded differently to hotel service experiences when making satisfaction judgement (Suki , 2014). The study of Frew and Shaw (1999) revealed that males and females were used different online tools (online \& mobile Internet) to search travel information in most of the tourist attraction destination. Furthermore, a study had confirmed that females have influence of psychological image on tourist expectation was significantly more powerful than male tourists (Wang, Qu, \& Hsu, 2016).

\section{Underlying Theory}

Understanding how attitude affect travelers' behavior is the main focus in the tourism and hospitality research (Zhang, Li, Yang, \& Zhang, 2018). Thus, Theory of Planned Behavior (TPB) is the most significant theory to study human act. Generally, TPB is an extension of the well-known Theory of Reasoned Action (TRA), which concentrating the promising factors that affecting individual intention and behavior. As noted in TPB literature, attitude toward behavior and subjective norms are create impact on intention (George, 2004). Moreover, control beliefs are reinforced behavioral control. These three main beliefs are used to measure human action, namely behavioral belief, normative beliefs, and control beliefs (Ajzen, 2002). Thus, perceived behavioral control is therefore enacted as alternative measure of actual control and confidence in an individual's ability (Armitage \& Christian, 2003). For TPB, intention are assumed to capture the motivational factors that lead to an individual's behavior and behavioral is depended on a person's motivation (intention) and his ability (behavioral control) (Ajzen, 1991). Therefore, when there is an opportunity to act, a person's intention may result in 
Borneo Journal of Social Science and Humanities

DOI: https://doi.org/10.35370/bjssh.2020.2.1-09

e-ISSN: 2682-8235

(C) 2018, UCTS Publisher.

Submitted: 06 June 2020

Accepted: 11 June 2020

Published: 30 June 2020

behavior. In the current study, an individual's performance of behavior (a traveler's intention to travel) is a function of intentions and perceived behavioral control (Ajzen, 1991) and determined by his or her intent to perform that particular behavior.

\section{Hypotheses Development}

\section{Life satisfaction}

Ajzen and Madden (1986) revealed that an individual act is used to predict an intention (Jamaludin, Sam, Sandal, \& Adam, 2016). Several studies had tested the relationship between life satisfaction and their decision on activities to be chosen (Diener, Kanazawa, Suh, \& Oishi, 2015; Otrachshenko \& Popova, 2014). The study of Graham and Markowitz (2011) found that life satisfaction contributed to intention to stay at the similar destination (Jamaludin et al., 2016). Subsequently, the following hypotheses was formulated:

H1: Life satisfaction is positively related to tourists' outbound travel intention.

\section{Online Marketing Communication}

In this social-networking era, people can use variety of networks to link up, such as, Facebook, Instagram, etc. As stated, the tourism and hospitality industry is highly influenced by the use of social media (Hur, Kim, Karatepe, \& Lee, 2017). An interactive media allows two way communication, which e-marketers can effectively communicate with their prospective travelers. According to Verbeke, Viaene, and Guiot (1999), marketing communication influence attitudes and in turn it create an impact on individual's behavior (Thaichon \& Quach, 2016). For example, online advertisement can strengthen an individual behavior meanwhile it may reduce unwanted behavior. It is therefore to conclude that the importance of online marketing communication on tourism had been widely because especially in this worldwide adoption of internet technologies. Based on above discussion, the researcher has proposed the following propositions:

$\mathrm{H} 2$ : Online marketing communication is positively related to tourists' outbound travel intention.

$e W O M$

EWOM is an imperative information source that influencing tourists travel decision and choice of travel destination (Chen, Dwyer, \& Firth, 2015; Vermeulen \& Seegers, 2009; Yun \& Good, 2007). This eWOM is referring to online reviews or messages sharing by e-consumers. A favorable eWOM can lead to tourist's willingness to stay with the destination but also can attract more potential travelers (Liu, Li, \& Kim, 2015). The study of Zhou and Lai (2009) revealed that online reviews and the tourists' blogs are significantly related to tourists' reception population (Meysam Fakharyan, Mohammad Reza Jalilvand, Mehdi Elyasi, \& Mehdi Mohammadi, 2012). Hence, online traveler reviews are important information sources to all travelers. Hereby, the researcher has made the following hypotheses:

H3: eWOM is positively related to tourists' outbound travel intention.

\section{Personal Involvement}

Involvement, generally, is acknowledged as personal connection with a particular event and the strategic approach to influence an individual person (Koo \& Ju, 2010). Personal involvement is used to examine temporary personal feeling of intense involvement (Gursoy \& Gavcar, 2003) and predict an individual attitude and behaviors (Havits \& Dimanche, 1990, as cited in Prayag \& Ryan, 2012). It is an ongoing commitment on the part of an individual with regard to thoughts, feelings, and behavioral responses to travel (Ferns \& Walls, 2012). The 
Borneo Journal of Social Science and Humanities

DOI: https://doi.org/10.35370/bjssh.2020.2.1-09

e-ISSN: 2682-8235

(C) 2018, UCTS Publisher.

Submitted: 06 June 2020

Accepted: 11 June 2020

Published: 30 June 2020

study of Shih (2009), the persistent involvement were significantly affected an individual revisit intention $(\mathrm{Li}, 2014)$. Hence, the fourth hypotheses are as follows:

H4: Personal Involvement is positively related to tourists' outbound travel intention.

\section{Novelty and knowledge}

Understanding of novelty seeking action is core element to define tourists' choice and their travel destination intention (Szivas \& Riley, 2004). In the context of travelling, novelty is used to explain new experience to explore a travel destination (Crompton, 1979). According to Ratchford (2001), pre-formed knowledge permit consumers to evaluate a product's attribute and benefits (Sharifpour, Walters, \& Ritchie, 2012). In fact, novelty seekers on average traveled are higher comparing to average travelers and familiarity seekers (Chark, Lam, \& Fong, 2020). The more familiar tourists were with a particular destinations, the less likely they were search for information about it (Sharifpour et al., 2012). Moreover, the empirical research study of Phillips, Asperin, and Wolfe (2013) discovered that subjective knowledge led to tourists' attitude toward Korean foods. Based on an ample body of literature, the researcher posits that the following hypothesis:

H5: Novelty and knowledge is positively related to tourists' outbound travel intention.

\section{Gender as Moderator}

Men and women are varying in terms of their thought, which caused by social, cultural, psychological, and environmental elements (Meyers-Levy \& Loken, 2015). Evidently, based on a survey analysis on 75,000 travelers, a significant gender influence had be found on individual destination choice (Krishnapillai \& Kwok, 2017). As reviewed in literature, male and female had varied information search behavior (John \& Sujan, 1990). Besides, the study also found that male are novelty seekers comparing to female (Weaver et al., 2009). According to $\mathrm{Li}$ (2006), men are more information-driven, however, women are more engagement approaches (McMahan, Hovland, \& McMillan, 2009). Furthermore, Dittmar, Long, and Meek (2004) discovered that men are differed from women in the respect to eWOM messages and their shopping behavior (Abubakar, 2016). In line with this, Harrant and Vaillant (2008) also found that women are reluctant to take risks comparing to men. Based on the existing findings, outlined above, gender are expected to moderate the relationship between life satisfaction, online marketing communication, eWOM, personal involvement, and novelty and knowledge and outbound travel intention, hence the hypotheses include:

H6: Gender moderate the relationship between life satisfaction and tourists' outbound travel intention.

H7: Gender moderate the relationship between online marketing communication and tourists' outbound travel intention.

H8: Gender moderate the relationship between eWOM and tourists' outbound travel intention. H9: Gender moderate the relationship between personal involvement and tourists' outbound travel intention.

H10: Gender moderate the relationship between novelty and knowledge and tourists' outbound travel intention.

\section{Methodology}

To collect the primary data, quantitative survey method had been used. The researcher is personally distributing the questionnaire to target respondents in selected four entry points, 
Borneo Journal of Social Science and Humanities

DOI: https://doi.org/10.35370/bjssh.2020.2.1-09

e-ISSN: 2682-8235

(C) 2018, UCTS Publisher.

Submitted: 06 June 2020

Accepted: 11 June 2020

Published: 30 June 2020

Miri Airport, Kuching Airport, Bintulu Airport, and Sibu Airport. Before distributing the questionnaire, the researcher will ask several filter questions to confirm the right respondents and avoid invalid responses. During the survey, if respondent is meeting the requirements of the study, the respondent will be given a complete set of questionnaire to fill. The population of interest in this study is Sarawakian who are travelling abroad for enjoyment in the past three months. A total of 500 questionnaire sets were distributed to respondents who travelled to the oversea. Out of the 411 returned questionnaires, 53 responses were discarded due to incomplete responses and excessive missing data. Roscoe (1975) suggested that sample sizes that are in the range if 30 to 500 are acceptable (Sekaran, 1992). All these representative respondents are drawn from different ethnic groups, occupations, education levels, age, with the condition that they fulfill all the basic requirements. Non-probability purposive and snowball sampling strategies were utilized as there are the most appropriate techniques to respondents who can provide valid information in turn to address the research questions. In total, 358 useable responses were collected, achieving a 71.6 percent response rate. The unit of analysis of the study is at the individual level.

To purify the measures, a pretest was conducted before the actual data collection. Responses from a convenience sample of 30 respondents were used to test the wording. Pretest permits the research to identify unclear wording which may lead to amendments and ensure that all designed measurement items, indicate types of difficulties in completing the questionnaire, and, if, possible to return the questionnaire immediately. This step was to uncover any potential problems. A questionnaire was then compiled based on the pretest. The questionnaire for the present study was divided into two main sections. The first sections contained measurement items to measure each construct and all these items were adapted from previously validated instruments. The construct travel intention was measured with the scales from Li and Cai (2016) and Bhattacherjee (2000), modified so that the focus was on the tourists' outbound travel intention. Measure of personal involvement is adapted from Prayag and Ryan (2015) and measured by five items. The dimension of online marketing communication was made up of five indicators and extracted from the study of Wongpitakroj (2017). The dimensions of life satisfaction and novelty and knowledge was generated predominately from $\mathrm{Li}$ and Cai (2016) and Jang and Wu (2006). Moreover, eWOM attributes were drawn from Jalilvand, Samiei, Dini, and Manzari (2012). The second section of the questionnaire consisted of questions regarding respondents' demographic characteristics. The research model had seven constructs, each having items that are gauged by Likert scale $(1=$ strongly disagree and $7=$ strongly agree).

To achieve objective, SmartPLS had been utilized as it is a commonly used statistical analysis method for latent variables. Reasons to use the PLS technique is that it is known as a sustainable method to estimate cause and effect relationships in complex models with large number of constructs (Gudergan, Ringle, Wende, \& Will, 2008) and makes practically no assumptions about underlying data (Fornell \& Bookstein, 1982). Additionally, PLS approach does not require a normal distribution (Henseler, Ringle, \& Sarstedt, 2012).

\section{Findings}

\section{Respondents' Demographic Characteristics}

The researcher utilised descriptive statistics to obtain the general information of the respondents. A complete demographic profile of the respondents is presented in Table 1. Of the total number of respondents, female recorded 196 (54.7 percent) and males stood at 162 
(45.3 percent), 244 respondents were still single and 114 were married. As for ethnicity compositions, Chinese were the largest group of respondents in this research, represented by 251 samples (70.1 percent), Malays were 18.7 percent $(n=67)$ followed by others $(n=39)$. This others are predominantly made up of Iban, Melanau, Kayan, and Kenyah. In terms of respondents' age, majority were 21 to 30 ( $n=189,52.8$ percent) followed by $31-40$ ( $n=97,27.7$ percent). This discovered that today's young Sarawakians' attitude towards holiday making are positive. The sample also consisted of 39 respondents (10.9 percent) from 41-50 years old group. Academically, the highest percentage were degree holders $(n=210,58.7$ percent $)$ followed by Diploma holders ( $n=86,24$ percent), and secondary school holders $(n=45,12.6$ percent). Next, the majority of respondents recorded an average income from RM3501RM5000, while 32.1 percent ( $n=115)$ were within the range of the range of RM2001-RM3500. For the employment rate, Most of the respondents were full time employees $(n=239)$. The second largest was others, which recorded 57 respondents.

Table 1 Demographic Information of Respondents

\begin{tabular}{|c|c|c|c|}
\hline \multicolumn{4}{|l|}{ Respondent $(\mathrm{n}=358)$} \\
\hline Demographic Variables & Category & Frequency & Percent (\%) \\
\hline \multirow[t]{2}{*}{ Gender of Respondent } & Male & 162 & 45.30 \\
\hline & Female & 196 & 54.70 \\
\hline \multirow[t]{6}{*}{ Age Category } & 20 and Below & 28 & 7.80 \\
\hline & $21-30$ & 189 & 52.8 \\
\hline & $31-40$ & 97 & 27.10 \\
\hline & $41-50$ & 39 & 10.90 \\
\hline & $51-60$ & 3 & 0.80 \\
\hline & 61 and Above & 2 & 0.60 \\
\hline \multirow[t]{4}{*}{ Ethnicity } & Malay & 67 & 18.70 \\
\hline & Chinese & 251 & 70.10 \\
\hline & Indian & 1 & 0.30 \\
\hline & Others & 39 & 10.90 \\
\hline \multirow{4}{*}{$\begin{array}{l}\text { Average Monthly Household } \\
\text { Income }\end{array}$} & RM2000 And Below & 81 & 22.60 \\
\hline & RM2001-RM3500 & 115 & 32.10 \\
\hline & RM3501-RM5000 & 131 & 36.60 \\
\hline & RM5001 And Above & 31 & 8.70 \\
\hline \multirow[t]{6}{*}{ Highest Education } & Primary School & 1 & 0.30 \\
\hline & Secondary School & 45 & 12.60 \\
\hline & Diploma & 86 & 24.00 \\
\hline & University Degree & 210 & 58.70 \\
\hline & Postgraduate Degree & 14 & 3.90 \\
\hline & Others & 2 & 0.6 \\
\hline \multirow[t]{2}{*}{ Marital Status } & Single & 244 & 68.20 \\
\hline & Married & 114 & 31.80 \\
\hline \multirow[t]{4}{*}{ Employment Status } & Full Time & 239 & 66.80 \\
\hline & Part-Time & 23 & 6.40 \\
\hline & Self-Employed & 39 & 10.90 \\
\hline & Others & 57 & 15.90 \\
\hline
\end{tabular}


Borneo Journal of Social Science and Humanities

DOI: https://doi.org/10.35370/bjssh.2020.2.1-09

e-ISSN: 2682-8235

(C) 2018, UCTS Publisher.

Submitted: 06 June 2020

Accepted: 11 June 2020

Published: 30 June 2020

\section{Travel Characteristics}

General travel characteristics of respondents were also analyzed as presented in Table 2. Approximately, 36.41 percent of the respondents were recorded visiting other Asian countries (such as, China, Taiwan, Hong Kong, Japan, South Korea, and India), 125 respondents are visited neighboring countries (such as Brunei, Indonesia, Singapore, Thailand, Vietnam, Myanmar, Cambodia, Laos, and Philippines), and 9.73 percent visited Oceania countries. Of the sample, a significant number, 212 respondents were traveled with partner. In terms of purpose of visit, 70.79 percent of respondents $(n=286)$ were likely to go for holiday instead of business trip (12.13 percent) and visiting friends and relatives (8.91 percent). This research also found that Sarawakian travel were preferred to travel by own arrangement.

Table 2 General Travel Information of Respondents

\begin{tabular}{llll}
\hline & & & Respondent (n=358) \\
\hline General Travel Information & Category & Frequency & Percent (\%) \\
\hline Where are you visit & Neighbouring Countries & 125 & 31.17 \\
destination? & Other Asia Countries & 146 & 36.41 \\
& Oceania Countries & 39 & 9.73 \\
& Western Countries & 91 & 22.69 \\
\hline Who are you travelling & Along & 29 & 6.86 \\
with? & Partner & 212 & 50.12 \\
& Family Members & 74 & 17.49 \\
& Friends and Relatives & 108 & 25.53 \\
\hline What is your purpose of & Holiday & 286 & 70.79 \\
visit? & Business & 49 & 12.13 \\
& Medical & 15 & 3.71 \\
& Visiting Friends and Relatives & 36 & 8.91 \\
& Honeymoon & 6 & 1.49 \\
& Others & 12 & 2.97 \\
\hline Are you taking any holiday & Yes & 133 & 37.20 \\
package for this trip? & No & 225 & 62.80 \\
\hline
\end{tabular}

Source: Author

\section{Assessment of Measurement Model Results}

The measurement model assessment identifies the causal relationship between the observed variables and latent variables. Convergent validity was assessed by factor loadings, composite reliability (CR), and Average Variance Extracted (AVE) (Fornell \& Larcker, 1981). As tabled in Table 3, as expected, the cross-loading for all items measured were loaded highly on its own construct than any other constructs. Table 4 presented that the item loadings range for each construct was 0.675 to 0.860 , which exceeded the cut-off value of 0.50 as suggested by (Hair, Ringle, \& Sarstedt, 2013). Thus, the internal consistency is achieved. As shown in Table 4, the AVE of each model construct exceeded the recommended threshold value of 0.50 (Fornell \& Larcker, 1981). Despite loadings and AVE, all constructs results of CR fulfilled the recommended value, 0.3, as recommended by Hair et al. (2008) and 0.7, as suggested by Gefen et al. (2000). Therefore, it can be inferred that the model's construct was good and sufficient for the research study. 
Borneo Journal of Social Science and Humanities

DOI: https://doi.org/10.35370/bjssh.2020.2.1-09

e-ISSN: 2682-8235

(C) 2018, UCTS Publisher.

Submitted: 06 June 2020

Table 3 Loading and Cross Loading

\begin{tabular}{|c|c|c|c|c|c|c|}
\hline & $\begin{array}{l}\text { Life } \\
\text { Satisfaction }\end{array}$ & $\begin{array}{l}\text { Marketing } \\
\text { Communica } \\
\text { tion }\end{array}$ & eWOM & $\begin{array}{l}\text { Personal } \\
\text { Involvement }\end{array}$ & $\begin{array}{l}\text { Novelty and } \\
\text { Knowledge }\end{array}$ & $\begin{array}{l}\text { Travel } \\
\text { Intention }\end{array}$ \\
\hline life_sat_1 & 0.757 & 0.289 & 0.195 & 0.245 & 0.206 & 0.210 \\
\hline life_sat_2 & 0.730 & 0.180 & 0.277 & 0.147 & 0.168 & 0.153 \\
\hline life_sat_3 & 0.743 & 0.114 & 0.307 & 0.241 & 0.179 & 0.169 \\
\hline life_sat_4 & 0.733 & 0.195 & 0.221 & 0.255 & 0.200 & 0.181 \\
\hline M_com_1 & 0.226 & 0.675 & 0.397 & 0.375 & 0.249 & 0.324 \\
\hline M_com_2 & 0.269 & 0.732 & 0.302 & 0.393 & 0.206 & 0.336 \\
\hline M_com_3 & 0.221 & 0.817 & 0.292 & 0.407 & 0.342 & 0.385 \\
\hline M_com_4 & 0.164 & 0.858 & 0.226 & 0.403 & 0.380 & 0.371 \\
\hline M_com_5 & 0.163 & 0.764 & 0.192 & 0.292 & 0.316 & 0.303 \\
\hline ewom_1 & 0.199 & 0.281 & 0.739 & 0.183 & 0.360 & 0.194 \\
\hline ewom_2 & 0.280 & 0.319 & 0.807 & 0.354 & 0.364 & 0.249 \\
\hline ewom_3 & 0.304 & 0.429 & 0.748 & 0.305 & 0.280 & 0.251 \\
\hline ewom_4 & 0.212 & 0.219 & 0.790 & 0.315 & 0.334 & 0.233 \\
\hline ewom_5 & 0.223 & 0.242 & 0.728 & 0.267 & 0.283 & 0.169 \\
\hline ewom_6 & 0.290 & 0.171 & 0.797 & 0.302 & 0.343 & 0.229 \\
\hline personal_Inv_1 & 0.273 & 0.288 & 0.273 & 0.730 & 0.395 & 0.577 \\
\hline personal_inv_2 & 0.270 & 0.284 & 0.295 & 0.739 & 0.409 & 0.507 \\
\hline personal_inv_3 & 0.219 & 0.343 & 0.326 & 0.781 & 0.413 & 0.490 \\
\hline personal_inv_4 & 0.178 & 0.405 & 0.235 & 0.793 & 0.407 & 0.559 \\
\hline personal_inv_5 & 0.204 & 0.524 & 0.308 & 0.721 & 0.315 & 0.503 \\
\hline nolvelty_k_1 & 0.131 & 0.306 & 0.379 & 0.439 & 0.835 & 0.428 \\
\hline novelty_k_2 & 0.201 & 0.366 & 0.328 & 0.467 & 0.855 & 0.441 \\
\hline novelty_k_3 & 0.246 & 0.282 & 0.399 & 0.315 & 0.681 & 0.304 \\
\hline novelty_k_4 & 0.252 & 0.279 & 0.270 & 0.394 & 0.783 & 0.418 \\
\hline travel_int_2 & 0.218 & 0.255 & 0.339 & 0.529 & 0.384 & 0.686 \\
\hline travel_int_3 & 0.173 & 0.279 & 0.160 & 0.444 & 0.264 & 0.699 \\
\hline travel_int_4 & 0.151 & 0.385 & 0.155 & 0.539 & 0.401 & 0.800 \\
\hline travel_int_5 & 0.206 & 0.428 & 0.238 & 0.619 & 0.476 & 0.860 \\
\hline
\end{tabular}

Note: Bold values are loadings for items that are above the recommended value 0.5.

Source: Author

Table 4 Results of Measurement Model

\begin{tabular}{llcccc}
\hline & $\begin{array}{l}\text { Measurement } \\
\text { Item }\end{array}$ & $\begin{array}{l}\text { Cronbach's } \\
\text { Alpha }\end{array}$ & $\begin{array}{l}\text { Factor } \\
\text { Loading }\end{array}$ & $\begin{array}{l}\text { Composite } \\
\text { Reliability } \\
\text { (CR) }\end{array}$ & $\begin{array}{l}\text { Average Variance } \\
\text { Extracted (AVE) }\end{array}$ \\
\hline Life Satisfaction & life_sat_1 & 0.728 & 0.757 & 0.829 & 0.548 \\
& life_sat_2 & & 0.730 & & \\
& life_sat_3 & & 0.743 & & \\
& life_sat_4 & & 0.733 & & \\
\hline
\end{tabular}


Borneo Journal of Social Science and Humanities

DOI: https://doi.org/10.35370/bjssh.2020.2.1-09

e-ISSN: 2682-8235

(C) 2018, UCTS Publisher.

Submitted: 06 June 2020

Accepted: 11 June 2020

Published: 30 June 2020

\begin{tabular}{|c|c|c|c|c|c|}
\hline Marketing & M_com_1 & 0.828 & 0.675 & 0.880 & 0.595 \\
\hline \multirow[t]{4}{*}{ Communication } & M_com_2 & & 0.732 & & \\
\hline & M_com_3 & & 0.817 & & \\
\hline & M_com_4 & & 0.858 & & \\
\hline & M_com_5 & & 0.764 & & \\
\hline \multirow[t]{6}{*}{ eWOM } & ewom_1 & 0.862 & 0.739 & 0.896 & 0.591 \\
\hline & ewom_2 & & 0.807 & & \\
\hline & ewom_3 & & 0.748 & & \\
\hline & ewom_4 & & 0.790 & & \\
\hline & ewom_5 & & 0.728 & & \\
\hline & ewom_6 & & 0.797 & & \\
\hline \multirow{5}{*}{$\begin{array}{l}\text { Personal } \\
\text { Involvement }\end{array}$} & personal_Inv_1 & 0.809 & 0.730 & 0.868 & 0.568 \\
\hline & personal_inv_2 & & 0.739 & & \\
\hline & personal_inv_3 & & 0.781 & & \\
\hline & personal_inv_4 & & 0.793 & & \\
\hline & personal_inv_5 & & 0.721 & & \\
\hline \multirow{4}{*}{$\begin{array}{l}\text { Novelty and } \\
\text { Knowledge }\end{array}$} & nolvelty_k_1 & 0.800 & 0.835 & 0.869 & 0.626 \\
\hline & novelty_k_2 & & 0.855 & & \\
\hline & novelty_k_3 & & 0.681 & & \\
\hline & novelty_k_4 & & 0.783 & & \\
\hline \multirow[t]{4}{*}{ Travel Intention } & travel_int_2 & 0.761 & 0.686 & 0.848 & 0.585 \\
\hline & travel_int_3 & & 0.699 & & \\
\hline & travel_int_4 & & 0.800 & & \\
\hline & travel_int_5 & & 0.860 & & \\
\hline
\end{tabular}

Note: a. Composite Reliability $(\mathrm{CR})=$ (square of the summation of the factor loadings)/ ( square of the summation of the factor loadings) + (square of the summation of the error variances) $\}$

b. Average Variance Extracted $(\mathrm{AVE})=$ (summation of the square of the factor loadings $) /\{($ summation of the square of the factor loadings) + (summation of the error variances) $\}$

Source: Author

Discriminant validity is used to ascertain the extent of dissimilarity between the intended measures and the measures used to designate the different constructs (Hung \& Petrick, 2012). To identify discriminant validity, both the Fornell and Larcker criterion and HTMT ratio were reported. Based on Fornell and Larcker (1981) criterion, the value of AVE is square rooted and it testifies against the inter-correlation of the construct with other constructs in the research model. As indicated in Table 5, the correlations for each of the constructs was less than the average variance extracted (in bold) by the indicators. Thus, this indicated that these underlined constructs were of adequate discriminant validity, which is based on the suggestions of Henseler, Ringle, and Sarstedt (2015). Further, HTMT Ratio was also tested to confirm discriminant validity. In HTMT, there are two criteria to follow in order to conclude that there is no problem of discriminant validity. These are the HTMT value that should not be greater than the $\mathrm{HTMT}_{0.85}$ value of 0.85 (Kline, 2011) or the $\mathrm{HTMT}_{0.90}$ value of 0.90 (Gold, Malhotra, \& Segars, 2001). HTMT is below 0.9. As demonstrated in Table 6, all the values exceeded the HTMT criterion which indicating that the discriminant validity has been established.

Table 5 Fornell-Larcker Criterion for Discriminant Validity of Constructs

\begin{tabular}{lllllll}
\hline & $\begin{array}{l}\text { Life } \\
\text { Satisfaction }\end{array}$ & $\begin{array}{l}\text { Marketing } \\
\text { Communication }\end{array}$ & $\begin{array}{l}\text { Novelty and } \\
\text { Knowledge }\end{array}$ & $\begin{array}{l}\text { Personal } \\
\text { Involvement }\end{array}$ & $\begin{array}{l}\text { Travel } \\
\text { Intention }\end{array}$ & eWOM \\
\hline Life Sat & $\mathbf{0 . 7 4 1}$ & & & & \\
\hline
\end{tabular}


Borneo Journal of Social Science and Humanities

DOI: https://doi.org/10.35370/bjssh.2020.2.1-09

e-ISSN: 2682-8235

(C) 2018, UCTS Publisher.

Submitted: 06 June 2020

Accepted: 11 June 2020

Published: 30 June 2020

\begin{tabular}{|c|c|c|c|c|c|c|}
\hline $\begin{array}{l}\text { Marketing } \\
\text { Communicati } \\
\text { on }\end{array}$ & 0.270 & 0.772 & & & & \\
\hline $\begin{array}{l}\text { Novelty and } \\
\text { Knowledge }\end{array}$ & 0.256 & 0.390 & 0.791 & & & \\
\hline $\begin{array}{l}\text { Personal } \\
\text { Involvement }\end{array}$ & 0.304 & 0.488 & 0.516 & 0.753 & & \\
\hline $\begin{array}{l}\text { Travel } \\
\text { Intention }\end{array}$ & 0.244 & 0.448 & 0.508 & 0.703 & 0.765 & \\
\hline eWOM & 0.331 & 0.365 & 0.426 & 0.379 & 0.292 & 0.769 \\
\hline
\end{tabular}

Source: Author

Table 6 HTMT Criterion for Discriminant Validity of Constructs

\begin{tabular}{|c|c|c|c|c|c|c|}
\hline & $\begin{array}{l}\text { Life } \\
\text { Satisfaction }\end{array}$ & $\begin{array}{l}\text { Marketing } \\
\text { Communication }\end{array}$ & $\begin{array}{l}\text { Novelty and } \\
\text { Knowledge }\end{array}$ & $\begin{array}{l}\text { Personal } \\
\text { Involvement }\end{array}$ & $\begin{array}{l}\text { Travel } \\
\text { Intention }\end{array}$ & eWOM \\
\hline $\begin{array}{l}\text { Life } \\
\text { Satisfactio } \\
\text { n }\end{array}$ & & & & & & \\
\hline $\begin{array}{l}\text { Marketing } \\
\text { Communi } \\
\text { cation }\end{array}$ & 0.339 & & & & & \\
\hline $\begin{array}{l}\text { Novelty } \\
\text { and } \\
\text { Knowledg } \\
\text { e }\end{array}$ & 0.342 & 0.477 & & & & \\
\hline $\begin{array}{l}\text { Personal } \\
\text { Involveme } \\
\text { nt }\end{array}$ & 0.389 & 0.596 & 0.634 & & & \\
\hline $\begin{array}{l}\text { Travel } \\
\text { Intention }\end{array}$ & 0.325 & 0.554 & 0.635 & 0.886 & & \\
\hline eWOM & 0.420 & 0.428 & 0.523 & 0.450 & 0.356 & \\
\hline
\end{tabular}

Note: HTMT < 0.85 (Kline, 2011), HTMT < 0.90 (Gold et al. 2001)

Source: Author

\section{Assessment of Structural Model Results}

Once the measurement model was validated, the structural model was then to be tested by analyzing the inner model. To test path analysis and hypotheses, the researcher used the bootstrapping technique to determine the significant t-statistic. Bootstrapping approach with 500 samples with 0 cases per sample to test the path coefficient $(\beta)$. The estimated standardized structural coefficients for the hypothesized relationship between constructs and their significance are revealed in Table 8. As illustrated in Figure 1, four out of 10 hypotheses tested are supported. The findings revealed that online marketing communication $(\beta=0.119, \mathrm{t}=2.699)$, personal involvement $(\beta=0.567, t=11.933)$, and novelty and knowledge $(\beta=0.183, t=3.945)$, and eWOM*gender $^{*}(\beta=0.089, \mathrm{t}=1.922)$ are positively significant in relation to tourists' outbound travel intention, supporting $\mathrm{H} 2, \mathrm{H} 4, \mathrm{H} 5$, and $\mathrm{H} 8$. Nonetheless, life satisfaction $(\beta=0.005, \mathrm{t}=0.100)$, eWOM $(\beta=0.049, \mathrm{t}=0.928)$, life satisfaction*gender $(\beta=0,011, \mathrm{t}=0.301)$, online marketing communication*gender $\quad(\beta=0.016, \quad \mathrm{t}=0.326), \quad$ and personal involvement*gender $(\beta=0.039, \mathrm{t}=0.697)$, therefore $\mathrm{H} 1, \mathrm{H} 3, \mathrm{H} 6, \mathrm{H} 7, \mathrm{H} 9$, and $\mathrm{H} 10$ are rejected. The variation inflation factor (VIF) values are also been reported in Table 7. Overall, the VIF 
values are ranged from 1.253 to 1.718 , which are less than 10 (Bock, Zmud, Kim, \& Lee, 2005). It is therefore to conclude that there is no multicollinearity exists among the constructs.

$\mathrm{R}^{2}$ can be assessed to obtain the predictive power of the structural model (Chin, 2010). The thumb of rule of R2 endogenous LVs was 0.67 (substantial), 0.33 (moderate), followed by 0.19 (weak) (Chin, 1998). In this study, the $\mathrm{R}^{2}$ value of this model was 0.543 . In this sense, the interaction were able to explain 54.3 percent of the variance of travel intention. Despite $\mathrm{R}^{2}$, the researcher now to access $\mathrm{Q}^{2}$. $\mathrm{Q}^{2}$ value can be assessed through cross-validated communality and cross-validated redundancy. According to Chin (1998), if a cross-validated redundancy reaches $\mathrm{Q}^{2}>0$ or the cut-off value of $\mathrm{Q}^{2}>0.5$, it implies that the model of study has predictive relevance, whereas, if $\mathrm{Q}^{2}<0$, then it means that it is a lack of predictive relevance (Barroso, Carrión, \& Roldán, 2010). The results of $\mathrm{Q}^{2}$ was 0.597 , which is more than zero value. Therefore, this study obtained a highly predictive model. The formula of predictive relevance is shown below:

$$
Q^{2}=1-\frac{\sum_{D} E_{D}}{\sum_{D} O_{D}}
$$

The results revealed a GoF value of $0.415\left(\mathrm{R}^{2}\right.$ was 0.543 , average AVE was 0.585). For the research model, which exceeds the cut-off value of 0.36 for large effect sizes of $R^{2}$ $\left(G o F_{\text {small }}=0.1, G o F_{\text {medium }}=0.25, G o F_{\text {large }}=0.36\right)($ Akter, D'Ambra, \& Ray, 2011). Hence, the researcher can confirm adequate support to validate the PLS model globally (Wetzels, Schroder, \& Oppen, 2009). The calculation of GoF was as follow:



Figure 1: Research Model with t-values 
Borneo Journal of Social Science and Humanities

DOI: https://doi.org/10.35370/bjssh.2020.2.1-09

e-ISSN: 2682-8235

(C) 2018, UCTS Publisher.

Submitted: 06 June 2020

Accepted: 11 June 2020

Published: 30 June 2020

Table 7 Path Coefficients and Hypothesis Testing

\begin{tabular}{clccccc}
\hline H & \multicolumn{1}{c}{ Relationship } & $\boldsymbol{\beta}$ & t-value & Supported & VIF & $\mathbf{f}^{2}$ \\
\hline H1 & $\begin{array}{l}\text { Life satisfaction is positively related to travel } \\
\text { intention }\end{array}$ & 0.005 & 0.100 & Not Supported & 1.253 & 0 \\
\hline H2 & $\begin{array}{l}\text { Online marketing communication is } \\
\text { positively related to travel intention }\end{array}$ & 0.119 & 2.699 & Supported & 1.476 & 0.021 \\
\hline H3 & eWOM is positively related to travel intention & -0.049 & 0.928 & Not Supported & 1.430 & 0.004 \\
\hline H4 & $\begin{array}{l}\text { Personal involvement is positively related to } \\
\text { travel intention }\end{array}$ & 0.567 & 11.933 & Supported & 1.673 & 0.420 \\
\hline H5 & $\begin{array}{l}\text { Novelty and knowledge is positively related } \\
\text { to travel intention }\end{array}$ & 0.183 & 3.945 & Supported & 1.551 & 0.047 \\
\hline H6 & $\begin{array}{l}\text { Gender moderated the relationship between } \\
\text { life satisfaction and travel intention }\end{array}$ & -0.011 & 0.301 & Not Supported & 1.272 & 0 \\
\hline H7 & $\begin{array}{l}\text { Gender moderated the relationship between } \\
\text { online marketing communication and travel } \\
\text { intention }\end{array}$ & -0.016 & 0.326 & Not Supported & 1.457 & 0.012 \\
\hline H8 & $\begin{array}{l}\text { Gender moderated the relationship between } \\
\text { eWOM and travel intention }\end{array}$ & 0.089 & 1.922 & Supported & 1.451 & 0.002 \\
\hline H9 & $\begin{array}{l}\text { Gender moderated the relationship between } \\
\text { personal involvement and travel intention }\end{array}$ & -0.039 & 0.697 & Not Supported & 1.718 & 0.002 \\
\hline H10 & $\begin{array}{l}\text { Gender moderated the relationship between } \\
\text { novelty and knowledge and travel intention }\end{array}$ & 0.041 & 0.792 & Not Supported & 1.554 & 0 \\
\hline
\end{tabular}

Note: $t$-value $>1.96\left(p<0.05^{*}\right) ; t$-value $>2.58\left(p<0.01^{* *}\right)$

Source: Author

\section{Discussion}

The findings from the analysis have raised several important points for discussion in this section. The purposes of the study were to investigate the influence of life satisfaction, personal involvement, online marketing communication, eWOM, and novelty and knowledge on travel intention in Sarawak context. Besides, researcher also explored the moderating effects of gender on all selected exogenous variables. Ten hypotheses were proposed and subsequently tested in the context of outbound tourism with 4 of them being supported and six of them being rejected (see Table 7).

As expected, the findings indicated that personal involvement yield the greatest significance for the element of personal involvement $(\mathrm{t}=11.933)$, novelty and knowledge $(t=3.945)$ followed by online marketing communication $(t=2.699)$ on tourist' outbound travel intention in Sarawak. This is perhaps a tourist with more personal involvement at the pre-tour research will certainly suggest greater destination verifications. This in turn may generate inner interest trough their pre-tour research and willingness to give intention to further understand and search relevant information (Thomas, 2012, as cited in $\mathrm{Li}$, 2014). Despite personal involvement, novelty and knowledge were significantly contribute to outbound travel intention. The result was in line with Jang and Feng (2007), that novelty seeking contributed revisit intention. This is in fact high novelty seeking tourists are more curios to search the relevant information and willing explore in turn to gain the experiences (Hsiao \& Yang, 2010). In the travel context, traveler may search, convert, process, and memorize the searched information for their travel journey (Lee, Chua, \& Han, 2016). Faison (1977) stated that a novel travel is 
Borneo Journal of Social Science and Humanities

DOI: https://doi.org/10.35370/bjssh.2020.2.1-09

e-ISSN: 2682-8235

(C) 2018, UCTS Publisher.

Submitted: 06 June 2020

Accepted: 11 June 2020

Published: 30 June 2020

characterized by new and unfamiliar experiences (Jang \& Feng, 2007). According to Plog (2001), adventures are always motivated by curiosities and individual desire to explore new things. Thus, novelty is essential to tourism decision making (Cohen, 1979). Apart from that, this study also indicated that online marketing communication led to outbound tourism intention among the Sarawakian. This is perhaps, the comments or review by travelers were easily to influence the new travelers to make travel intention. In sum, online marketing communication can be served as a marketing communication medium and a significant strategy to attract people to travel.

Unfortunately, life satisfaction and eWOM were insignificantly predict outbound travel intention among the Sarawakian although EWOM used as information sources for tourists. This current finding is similar with the finding of Oliveira and Huertas (2015) that life satisfaction was not lead to intention to use Facebook. This findings were also confirmed by the study of Jamaludin et al. (2016) that life satisfaction were not contribute to destination loyalty intention. This is, in fact, an individual person has different set of standard to judge and evaluate life satisfaction (Sam, 2001). Another reason could be due to the fact that life satisfaction was measured based on overall view without considering special tourists' cohort. Despite life satisfaction, the finding of Abubakar (2016) also discovered that eWOM didn't contribute to travel intention among the tourists in Cyprus.

A somewhat surprising result disclosed by the path coefficients is gender failed to moderate the relationship between life satisfaction, online marketing communication, personal involvement, novelty and knowledge and outbound tourism intention. Yoo and Zhao (2010) illustrated that gender played a no difference on convention travel decision (Ramirez, Laing, \& Mair, 2013). Results of the study were contrary with study of Weaver, Mccleary, Han, and Blosser (2009). They found that gender and education levels are significantly influence the US residents to visit Japan and Australia. Perhaps, majority of respondents (tourists) of this study are from similar cohort, they are in the age range of 21-30 years old. Li and Yang (2015) depicted that gender had no moderating effect on visitor's behavioral intention among the tourist in Macao. Venkatesh and Morris (2000) found that gender are equally attentive to social cues. Additionally, results of Maduku's study also exposed that gender have no significant moderating effects on social. The study of Wong, Yap, Turner, and Rexha (2011) designated that gender had no significant difference on adopter categories for email (Kim, 2015). It is however important to recognize that gender moderated the relationship between eWOM and tourist outbound travel intention. As noted, women are more relied on WOM comparing to men (Garbariono \& Strahilevits, 2004). The finding of this study is concurrent with the study of Abubakar (2016) that gender moderated the relationship between eWOM and intention to travel among the people from Cyprus. Thus, we cannot deny that eWOM is always affect individual's travel intention regardless of gender.

\section{Conclusions}

One of the novel findings of the present study is online marketing communication, personal involvement, and novelty and knowledge had a direct influence on outbound tourism intention in the context of Sarawak. In term of indirect relationship, gender is only moderate the relationship between eWOM and outbound travel intention among the local people (tourists). Overall, the study highlights the importance of significant variables that predicting the Sarawakian outbound travel behaviour. It also offers valuable insight to Ministry of Tourism and Arts which could lead to develop their tourism attraction strategies and improve the 
Borneo Journal of Social Science and Humanities

DOI: https://doi.org/10.35370/bjssh.2020.2.1-09

e-ISSN: 2682-8235

(C) 2018, UCTS Publisher.

Submitted: 06 June 2020

Accepted: 11 June 2020

Published: 30 June 2020

marketing promotions in order to attract local people to visit locally. To attract and market the local people to travel locally, local tourism managers should identify that local people are considered to use online forum and often will not reserve without seeking online advices on tourism destination. Moreover, it is important for destination marketers to understand the drivers of tourist outbound travel intention because the cost to remain a tourist is much lower comparing to a new tourist (Um, Chon, \& Ro, 2006). The findings also contribute to local government and its related policy makers and legislative authorities need to address the outcomes of this study in a way that reflects positively on controlling outbound and inbound tourism and at the same time encourages domestic tourism. Additionally, results also are highly advisable to destination marketing managers and travel agencies to utilize the social media in informing Sarawakian as Sarawak has countless of tourism destination. In summary, to promote local tourism, it is crucial to understand local peoples' travel behavior or motives (explicit and implicit), as such an understanding offers a better explanation of the motives behind tourists' behavior and thus allows tourism planners to foresee tourists' actions.

\section{Acknowledgement}

The author(s) disclosed receipt of the following financial support for the research and/or publication of this article. This research study was supported by University College of Technology Sarawak under research grant (UCTS/RESEARCH/2/2019/07).

\section{References}

Abubakar, A.M. (2016). Does Ewom inluence destination trust and travel intention: a medical tourism perspective. Economic Research-EKONOMSKA ISTRAZIVANJA, 29(1), 598-611.

Abubakar, A.M., \& Ilkan, M. (2013). More adverts or more eWOM's. Journal of Business and Financial Affairs, 2(2), 129.

Ahn, T., Ekinci, Y., \& Li, G. (2013). Self-congruence, functional congruence, and destination choice. Journal of Business Research, 66(6), 719-723.

Ajzen, I. (1991). The Theory of Planned Behavior. Organizational Behavior and human decision processes, 50, 179-211.

Ajzen, I (2002). Perceived behavioral control, self-efficacy, locus of control, and the theory of planned behavior. Journal of Applied Social Psychology, 32(4), 665-683.

Akter, S., D'Ambra, J., \& Ray, P. (2011). Trustworthiness in mHealth Information Services: An assessment of a hierarchical model with mediating and moderating effects using Partial Least Squares (PLS). Journal of The American Society For Information Science And Technology, 62(1), 100-116.

Amalia, R., Yahya, A., Nurhalis, Idris, S., Mahdi, S., Putra, T.R., \& Sartiyah. (2018). Impact of electronic word of mouth on tourist attitude and intention to visit islamix destinations. 1st Aceh Global Conference (AGC 2018) (pp. 700-708). Banda Aceh, Indonesia: Atlantis Press.

Angelopulo, G. (1996). Introduction to Communication: Speech Communication, Public Relations and Advertising: Coursebook (Introduction to Communication) (Book 7). Kenwyn: Juta Academic.

Arndt, J. (1967). Role of product-related conversations in the diffusion of a new product. Journal of Marketing Research, 4(3), 291-295. 
Borneo Journal of Social Science and Humanities

DOI: https://doi.org/10.35370/bjssh.2020.2.1-09

e-ISSN: 2682-8235

(C) 2018, UCTS Publisher.

Submitted: 06 June 2020

Accepted: 11 June 2020

Published: 30 June 2020

Armitage, C.J. \& Christian, J. (2003). From attitudes to behavior: basic and applied research on the theory of planned behavior. Current Psychology, 1-9.

Bai, B., Hu, C., \& Wu, E. (2009). Affect, travel motivation, and travel intention: A senior market. Journal of Hospitality \& Tourism Research, 33(1), 51-73.

Bai, X., Hung, K., \& Lai, D.W. (2017). The role of travel in enhancing life satisfaction among Chinese older adults in Hong Kong. Ageing and Society, 37(9), 1824-1848.

Barroso, C., Carrión, G.C., \& Roldán, J.L. (2010). Applying Maximum Likelihood and PLS On Different Sample Sizes: Studies on SERVQUAL Model and Employee Behavior Model. In Handbook of Partial Least Squares: Concept, Methods and Applications by Esposito, V., et al., (Eds). P. 427-447.

Bock, G.W., Zmud, R.W., Kim, Y.G., \& Lee, J.N. (2005). Behavioral intention formation in knowledge sharing: Examining the roles of extrinsic motivators, social-psychological forces, and organizational climate. MIS Quarterly, 29(1), 87-111.

Chan, G.S., Lee, A.L., \& Wong, C.H. (2018). Celebrity endorsement in advertisement on destination chioce among generation $\mathrm{Y}$ in Hong Kong. International Journal of Marketing Studies, 10(2), 16-27.

Chark, R., Lam, L.W., \& Fong, L.H.N. (2020). Morning larks travel mode that night owls? Chronotypical effect on trvel frequency through novelty seeking. Tourism Management, 77, 1-11.

Chen, C.C., Petrick, J.F., \& Shahvali, M. (2014). Tourism experiences as a stress reliever: Examining the effects of tourism recovery experiences on life satisfaction. Journal fo Travel Research, 55(2), 150-160.

Chen, N., Dwyer, L., \& Firth, T. (2015). Factors influencing Chinese students' behavior in promoting Australis as a destination for Chinese outbound travel. Journal of Travel \& Tourism Marketing, 32, 366-381.

Chen, Y.C., Shang, R.A., \& Li, M. (2014). The effects of perceived relevance of travel blogs' content on the behavioral intention to visit a tourist destination. Computers in Human Behaviour, 30(1), 787-799.

Chen, Y., Lehto, X.Y., \& Cai, L. (2013). Vacation and well-being: A study of chinese tourists. Annals of Tourism Research, 42(1), 284-310.

Chin, W.W. (2010). How to Write Up and Report PLS Analyses. In Handbook of Partial Least Squares: Concept, Methods and Applications by Esposito, V., et al., (Eds). P. 655-690.

Chin, W. (1998). Issues and Opinions on Structural Equation Modeling. MIS Quarterly, 22(1): 7-16.

Choong, D. \& Hedrick-Wong, Y. (2017). Mastercard future of outbound travel in Asia Pacific (2016 to 2021) Report. Retrieved from https://newsroom.mastercard.com/asiapacific/files/2017/01/Mastercard-Future-of-Outbound-Travel-Report-2016-2021Asia-Pacific1.pdf

Chow, W.S. \& Chan, L.S. (2008). Social network, social trust, and shared goals in organizational knowledge sharing. Information \& Management, 45, 458-465.

Cohen, E. (1979). Rethinking the sociology of tourism. Annals of Tourism Research, 6(1), 1835.

Crompton, J.L. (1979). Motivation for pleasure vacation. Annals of Tourism Research, 6(4), 408-424.

Department of Statistic Malaysia. (2019). Tourism Satellite Account 2018. Retrieved from https://www.dosm.gov.my/ 
Borneo Journal of Social Science and Humanities

DOI: https://doi.org/10.35370/bjssh.2020.2.1-09

e-ISSN: 2682-8235

(C) 2018, UCTS Publisher.

Submitted: 06 June 2020

Accepted: 11 June 2020

Published: 30 June 2020

Diener, E., Kanazawa, S., Suh, E.M., \& Oishi, S. (2015). Why people are in a generally good mood. Personality and Social Psychology Review, 19(3), 235-256.

Dillette, A., Douglas, A., \& Martin, D. (2018). Do vacations really make us happier? Exploring the relationships between wellness tourism, happiness and quality of life. Journal of Tourism and Hospitality, 7(3), 1-10.

Elsrud, T. (2001). Risk creation in traveling: Backpacker adventure narration. Annals of Tourism Research, 28(3), 597-617.

Ferns, B.H. \& Walls, A. (2012). Enduring travel involvement, destination brand equity, and travelers' visit intentions: a structural model analysis. Journal of Destination Marketing \& Management, 1, 27-35.

Fornell, C. \& Bookstein, F.L. (1982). Two structural equation models: LISREL and PLS applied to consumer exit-voice theory. Journal of Marketing Research, 19, 440-452.

Fornell, C. \& Larcker, D. (1981). Evaluating structural equation models with unobservable variable and measurement error. Journal of Marketing Research, 18(1), 39-50.

Frew, E.A. \& Shaw, R.N. (1999). The relationship between personality, gender, and tourism behaviour. Tourism Management, 20(2), 193-202.

Garbarino, E. \& Strahilevitz, M. (2004). Gender differences in the perceived risk of buying online and the effects of receiving a site recommendation. Journal of Business Research 57: 768-75.

George, J.F. (2004). The theory of planned behavior and internet purchasing. Internet Research, 14(3), 198-212.

Gursory, D. \& Gavcar, E. (2003). International leisure tourists' involvement profile. Annals of Tourism Research, 30(4), 906-926.

Gold, A.H., Malhotra, A., \& Segars, A.H. (2001). Knowledge management: an organizational capabilities perspective. Journal of Management Information Systems, 18(1), 185-214.

Gudergan, S.P., Ringle, C.M., Wende, S., \& Will, A. (2008). Confirmatory tetrad analysis for evaluating the mode of measurement models in PLS path modeling. Journal of Business Research, 61, 1238-1249.

Han, H., Hsu, L.T., \& Lee, J.S. (2009). Empirical investigation of the roles of attitudes touward green behaviours, overall image, gender, and age in hotel customers' eco-friendly decision-making process. International Journal of Hospitality Management, 28(4), 519-528.

Harrant, V. \& Vaillant, N.G. (2008). Are women less risk averse than men? Evolution and Human Behaviour, 29, 396-401.

Henseler, J., Ringle, C.M., \& Sarstedt, M. (2015). A new criterion for assessing discriminant validity in variance-based structural equation modeling. Journal of the Academy of Marketing Science, 43(1), 115-135.

Henseler, J., Ringle, C.M., \& Sarstedt, M. (2012). Using partial least squares path modeling in international advertising research: basic concepts and recent issues. In S. Okazaki (Ed.), Handbook of research in international advertising (pp.252-276).

Hsiao, C.H. \& Yang, C. (2010). Predicting the travel intention to take high speed rail among college students. Transportion Research Part, 13, 277-287.

Hulusic, V. \& Rizvic, S. (2013). Story guided virtual environments in educational applications. In Lecture Notes in Computer Science (LNCS, volume 7544) (pp. 132-149). Heidelberg, Germany: Springer-Verlag Berlin Heidelberg. 
Borneo Journal of Social Science and Humanities

DOI: https://doi.org/10.35370/bjssh.2020.2.1-09

e-ISSN: 2682-8235

(C) 2018, UCTS Publisher.

Submitted: 06 June 2020

Accepted: 11 June 2020

Published: 30 June 2020

Hung, K. \& Petrick, F.F. (2012). Testing the effects of congruity, travel constraints, and selfefficacy on travel intentions: an alternative decision-making model. Tourism Management, 33, 855-867.

Hur, K., Ki, T.T., Karatepa, O.M., \& Lee, G. (2017). An exploration of the factors infeuncing social media continuance usage and information sharing intentions among Korean travellers. Tourism Management, 63, 170-178.

Ivlevs, A. (2015). Happy moves? Assessing the link between life satisfaction and emigration intentions. Kyklos, 68(3), 335-356.

Jain, R. (2014). Cultivating relationship with tourists: Role of public relations in constructing and promoting authentic experiences. Public Relations Journal, 8(4), 1-27.

Jamaludin, N.L., Sam, D.L., Sandal, G.M., \& Adam, A.A. (2016). The influence of perceived discrimination, orientation to mainstream culture and life satisfaction on destination loyalty intentions: the case of international students. Current Issues in Tourism, 1-18.

Jang, S. \& Feng, R. (2007). Temporal destination revisit intention: The effects of novelty seeking and satisfaction. Tourism Management, 28(1), 580-590.

John, D. \& Sujan, M. Differences in product categorization. Journal of Consumer Research, $16,452-460$.

Johnson, B.T. \& Eagly, A. (1989). Effects of involvement on persuasion: A meta-analysis. Psychological Bulletin, 106(2), 290-314.

Josiam, B.M., Smeaton, G., \& Clements, C.J. (1999). Involvement: travel motivation and destination selection. Journal of Vacation Marketing, 5(2), 167-175.

Kim, J. (2015). An extended technology acceptance model in behavioral intention toward hotel tablet apps with moderating affects of gender and age. International Journal of Contemporary Hospitality Manegement, 28(8), 1-37.

Kim, S.-B. \& Kwon, K.-J. (2018). Examining the relationships of image and attitude on visit intention to Korea among Tanzanian college students: The moderating effect of familiarity. Sustainability, 10(360), 1-15.

King, C. \& Grace, D. (2013). Travel decision making an empirical examination of generational values, attitudes, and intentions. Journal of Travel Research, 52(3), 310-324.

Kline, R.B. (2011). Principles and practice of structural equation modeling. New York: Guilford Press.

Krippendorf, J. (1987). The holiday makers. London: Heinemann.

Krishnapillai, G. \& Kwok, S.Y. (2017). The influence of e-WOM on travel intention among foreign students in Malaysia: does gender really Matter? International Review of Management and Marketing, 7(1), 475-483.

Koo, D.M. \& Ju, S.H. (2010). The interactional effects of atmospherics and perceptual curiosity on emotions and online shopping intention. Comput. Hum. Behav, 26, 377-388.

Ladhari, R. \& Michaud, M. (2015). EWOM effects on hotel booking intentions, attitudes, trust, and website perceptions. International Journal of Hospitality Management, 46(1), 3645.

Lambin, J. (1997). Strategic marketing. London: McGraw Hill.

Lee, S., Chua, B.L., \& Han, H. (2016). Role of service encounter and physical environment performances, novelty, satisfaction and affective commitment in generating cruise passenger loyalty. Asia Pacific Journal of Tourism Research, 1-17.

Lee, T.H. \& Crompton, J. (1992). Measuring novelty seeking in tourism. Annals of Tourism Research, 19(4), 732-751. 
Borneo Journal of Social Science and Humanities

DOI: https://doi.org/10.35370/bjssh.2020.2.1-09

e-ISSN: 2682-8235

(C) 2018, UCTS Publisher.

Submitted: 06 June 2020

Accepted: 11 June 2020

Published: 30 June 2020

Li, J. \& Yang, Y. (2015). Describing and testing gender as moderator: illustrated substantively with a hypothesized relation between image, satisfaction, and behavioral intentions. Anatolia-An International Journal of Tourism and Hospitality Research, 26(2), 258268.

Liu, X., Li, J.Justin., \& Kim, W.G. (2015). The role of travel experience in the structural relationships among tourists' perceived image, satisfaction, and behavioral intentions. Tourism and Hospitality Research, 1-12.

Li, Y.M. (2014). Effects of story marketing and travel involvement on tourist behavioural intention in the tourism industry. Sustainability, 6(1), 9387-9397.

Lu, J., Hung, K., Wang, L., Schuett, M.A., \& Hu, L. (2016). Do perceptions of time affect outbound-travel motivations and intention? An investigation among Chinese seniors. Tourism Management, 53(1), 1-12.

Madrigal, R., Havitz, M.E., \& Howard, D.R. (1992). Married couples' involvement with family vacations. Leisure Sciences, 14(4), 287-301.

Maduku, D.K (2015). Understanding behavioral intention towards e-books use: does gender really matter? Proceeding of $31^{\text {st }}$ International Business Research Conference, 27-29 July 2015, Ryerson University, Toronto, Canada.

McMahan, C., Hovland, R., \& McMillan, S. (2009). Online marketing communications: exploring online consumer behavior by examining gender differences and interactivity within internet advertising. Journal of Interactive Advertising, 10(1), 61-76.

Meyers-Levy. J. \& Loken, B. (2015). Revisiting gender differences: what we know and what lies ahead. Journal of Consumer Psychology, 25, 129-149.

Meysam Fakharyan., Mohammad Reza Jalilvand., Mehdi Elyasi., \& Mehdi Mohammadi. (2012). The influence of online word of mouth communications on tourists' attitudes toward Islamic destinations and travel intention: Evidence from Iran. African Journal of Business Management, 6(38), 10381-10388.

Mohd Hafiz Mohd Hanafiah., Zulhan Othman., Muhammad Izzat Zulkifly., Hazmal Ismail., \& Mohd Raziff Jamaluddin. (2010). Malaysian tourists' motivation towards outbound tourism. Retrieved from https://d1wqtxts1xzle7.cloudfront.net/

Okazaki, S. \& Hirose, M. (2009). Does gender affect media affect chioce in travel information search? On the use of mobile internet. Tourism Management, 30(6), 794-804.

Oliveira, M.J.De. \& Huertas, M.K.Z. (2015). Does life satisfaction influence the intention (weintention) to use Facebook?. Computers in Human Behaviour, 50, 205-210.

Otrachshenko, V. \& Popova, O. (2014). Life (dis) satisfaction and the intention to migrate: Evidence from Central and Eastern Europe. The Journal of Socio-Economics, 48, 4049.

Pabel, A. \& Prideaux, B. (2016). Social media use in pre-trip planning by tourists visiting a small regional leisure destination. Journal of Vacation Marketing, 22(4), 335-348.

Pan, B., MacLaurin, T., \& Crotts, J. (2007).Travel blogs and the implications for destination marketing. Journal of Travel Research, 46(1), 35-45.

Park, S.-H., Mahony, D., \& Kim, Y.K. (2011). The role of sport fan curiosity: A new conceptual approach to the understanding of sport fan behaviour. Journal of Sport Management, 25(1), 46-56.

Pawar, A.V. (2014). Study of the effectiveness of online marketing on integrated marketing communication. Master thesis, School of Management, D.Y. Patil University, Navi Mumbai. 
Borneo Journal of Social Science and Humanities

DOI: https://doi.org/10.35370/bjssh.2020.2.1-09

e-ISSN: 2682-8235

(C) 2018, UCTS Publisher.

Submitted: 06 June 2020

Accepted: 11 June 2020

Published: 30 June 2020

Plog, S. (2001). Why destination areas rise and fall in popularity: An update of a Cornell Quarterly classic. Cornell Hotel and Restaurant Administration Quarterly, 42(3), 1-12.

Prayag, G. \& Ryan, C. (2012). Antecedents of tourists' loyalty to Mauritius: the role and infleunce of destination image, place attachement, personal involvement, and satisfaction. Journal of Travel Research, 51(3), 342-356.

Ramirez, D., Laing, J., \& Mair, J. (2013). Exploring intentions to attend a convention: a gender perspective. Event Management, 17, 165-178.

Rothschild, M.L. (1984). Perspectives on involvement: Current problems and future directions. Advances in Consumer Research, 11(1), 216-217.

Sam, D.L. (2001). Satisfaction with life among international students: An exploratory study. Social Indicators Research, 53(3), 315-337.

Sharifpour, M., Walters, G., \& Ritchie, B.W. (2012). Risk perception, prior knowledge, and willingness to travel: investigating the Australian tourist market's risk perceptions towards the Middle East. Journal of Vacation Marketing, 20(2), 111-123.

Shih, C. (2009). The Facebook era: Tapping online social networks to build better products, reach new audiences, and sell more stuff. New Jersey, United States: Prentice Hall.

Singh, S. \& Srivastava, P. (2019). Social media for outbound leisure travel: a framework based on technology acceptance model (TAM). Journal of Tourism Futures, 5(1), 43-61.

Soleimani, A.G. \& Einolahzadeh, H. (2018). The influence of service quality on revisit intention: The mediating role of WOM and satisfaction (Case study: Guilan travel agencies). Cogent Social Sciences, 4(1), 1-14.

Suki, N.M. (2014). Moderating role of gender in the relationship between hotel service quality dimensions and tourist safisfaction. Journal of Quality Assurance in Hospitality and Tourism, 15(1), 44-62.

$\mathrm{Su}, \mathrm{L}$. \& Huang, Y. (2019). How does perceived destination social responsibility impact revisit intentions: The mediating roles of destination preference and relationship quality. Sustainability, 11(1), 133.

Scivas, E. \& Rikey, M. (2004). Destination loyalty and repeat behavior: an application of optimum stimulation measurement. International Journal of Tourism Research, 6, 439447.

Thaichon, P. \& Quach, T.N. (2016). Online marketing communications and childhood's intention to consume unhealthy food. Australasian Marketing Journal, 1-7.

Tsai, L. (2015). Culinary tourism and night markets in Taiwan. International Journal of Business and Information, 8(2), 247-266.

Tsaur, S.H., Yen, C.H., \& Hsiao, S.L. (2013). Transcendent experience, flow and happiness for Mountain Climbers. International Journal of Tourism Research, 15(4), 360-374.

Um, S., Chon, K., \& Ro, Y.H. (2006). Antecedents of revisit intention. Annals of Tourism Research, 33(4), 1141-1158.

Venkatesh, V. \& Morris, M.G. (2000). Why don't men ever stop to ask for directions? Gender, social influence, and their role in technology acceptance and usage behaviour'. MIS Quarterly, 24(1), 115-139.

Vermeulen, I.E. \& Seegers, D. (2009). Tried and tested: The impact of online hotel reviews on consumer consideration. Tourism Management, 30(1), 123-127.

Veenhoven, R. (1996). The study of life satisfaction. In W. Saris, R. Veenhoven, A. Scherpenzeel, \& B. B. Bunting, A comparative study of satisfaction with life in Europe (pp. 11-48). Budapest: Eötvös University Press. 
Wang, C., Qu, H., \& Hsu, M.K. (2016). Toward an integrated model to tourist expectation formation and gender difference. Tourism Management, 54(1), 58-71.

Weaver, P.A., Mccleary, K.W., Han, J., \& Blosser, P.E. (2009). Identifying leisure travel market segments based on preference for novelty. Journal of Travel \& Tourism Marketing, 26, 568-584.

Wetzels, M., Schroder, G.O., \& Oppen, V.C. (2009). Using PLS path modeling for assessing hierarchical construct models: Guidelines and empirical illustration. MIS Quarterly, 33(1), 177-195.

Yiamjanya, S. \& Wongleedee, K. (2014). International tourists' travel motivation by push-pull factors and the decision making for selecting Thailand as destination choice. International Scholarly and Scientific Research and Innovation, 8(5), 1348-1353.

Yun, Z.S. \& Good, L.K. (2007). Developing customer loyalty from e-tail store image attributes. Manag. Serv. Qual. 17(1):4-22.

Zhang, H., Li, L., Yang, Y., \& Zhang, J. (2018). Why do domestic tourists choose to consume local food? The differential and non-monotonic moderating effects of subjective knowledge. Journal of Destination Marketing \& Management, 10, 68-77. 